\title{
Long-distance wind-borne dispersal of the moth Cornifrons ulceratalis (Lepidoptera: Crambidae: Evergestinae) into the northern Mediterranean
}

\author{
Jordi DANTART ${ }^{1}$, CONSTANTi STEFANESCU ${ }^{2}$, ANNA ÀVILA ${ }^{3}$ and MARTA ALARCÓN ${ }^{4}$ \\ ${ }^{1}$ Museu de Ciències Naturals de Barcelona (Zoologia), Passeig Picasso, s/n, E-08003 Barcelona, Spain; e-mail: jdantart@xtec.net \\ ${ }^{2}$ Butterfly Monitoring Scheme, Museu de Granollers de Ciències Naturals, Francesc Macià, 51, E-08402 Granollers, Spain \\ ${ }^{3}$ Centre for Ecological Research and Forestry Applications, Edifici C, Universitat Autònoma de Barcelona, E-08193 Bellaterra, \\ Spain \\ ${ }^{4}$ Departament de Física i Enginyeria Nuclear, Universitat Politècnica de Catalunya, Urgell 187, E-08036 Barcelona, Spain
}

Key words. Cornifrons ulceratalis, Crambidae, moth, wind-borne migration, pied piper phenomenon, north-western Mediterranean

\begin{abstract}
On October 2006, during an episode of abnormally warm weather, the African moth Cornifrons ulceratalis (Lederer, 1858) was captured simultaneously for the first time in several sites in north-eastern Spain, the Balearic Islands and southern France. A deep depression situated over the Atlantic at the time gave rise to warm south-westerly winds, accompanied by suspended dust, that blew towards the north-western Mediterranean Basin. Back trajectories of air masses at two different altitudinal levels indicate that the moths most probably originated from an area located in Morocco and northern Algeria, where C. ulceratalis can be extremely abundant. With winter approaching, this invasion of a typically non-migratory species into the north-western Mediterranean Basin provides a good example of the so-called "pied piper" phenomenon, by which wind-borne insects may be carried into areas unfavourable for survival or reproduction. However, because climate change may make the establishment of this and other African species more likely in the future, we suggest that monitoring of this process may become an essential issue in the coming years.
\end{abstract}

\section{INTRODUCTION}

Long-distance wind-borne movements are known for a wide range of insect taxa, including nocturnal moths (Johnson, 1969; Mikkola, 1986; Drake \& Farrow, 1988; Gatehouse, 1997). Strong evidence for the occurrence of this phenomenon in migrant Lepidoptera was provided by early entomologists using synoptic weather maps and the back-tracking of air masses that satisfactorily explained the appearance of species of African and Asian origin in northern Europe (e.g. Kettlewell \& Heard, 1961; Mikkola, 1967; French, 1969). The development of entomological radars, in conjunction with conventional and aerial trapping data, has further confirmed that the wind-borne transport of moths occurs at high altitudes (Reynolds \& Riley, 1997; Chapman et al., 2002, 2008; Westbrook, 2008).

Although some seasonal migrants take advantage of prevailing air currents for successfully exploiting temporary breeding habitats (Johnson, 1995; Pedgley et al., 1995; Chapman et al., 2008), wind-borne transport also implies the risk that it may lead insects into areas unfavourable for survival or reproduction (the so-called "pied piper" phenomenon: McNeil, 1987). In Europe this happens fairly frequently during the autumn (Bretherton, 1983), when occasional spells of warm African winds are associated with otherwise abnormal records of subtropical moths (e.g. Brown, 1996). This "pied piper" phenomenon is much more evident when non-recognized migrant species that clearly have evolved no mechanisms for facili- tating return migrations appear outside their normal distribution ranges (see also Walker, 1980).

In October 2006, while trapping moths in the Spanish Pyrenees during two consecutive and unusually warm nights, we captured several individuals of the crambid Cornifrons ulceratalis (Lederer, 1858) (Fig. 1). Although this moth occurs throughout northern Africa, the Canary Islands, some of the Mediterranean islands and Iran (Goater, 2005), it has only quite exceptionally been recorded in southern Europe, where it is not known as a migrant species. On the same days as our captures in the Pyrenees, other specimens were recorded in the Balearic Islands and southern France (Geniez et al., 2007; Honey et al., 2007; Marney \& Marney, 2007). These captures coincided with high levels of Saharan dust in suspension over Mallorca, which led Honey et al. (2007) to suggest that they were the result of a migration. Here we provide an overview of the invasion of $C$. ulceratalis into the north-western Mediterranean Basin and investigate its possible association with winds originating from synoptic-scale systems over Africa. We confirm Honey's et al. (2007) suggestion and back-track the air masses at two different altitudinal levels to identify the probable source areas of this migratory influx.

\section{MATERIAL AND METHODS}

Light-trapping was carried out by the senior author on the nights of 27 and 28 October 2006 in two areas situated at 1,310 and $1,395 \mathrm{~m}$ above sea level (a.s.1.) in the Catalan Pyrenees (Pallars Sobirà, north-eastern Spain; see details in Table 1). On both nights one mercury-vapour lamp was used from sunset to 1 
TABLE 1. Records of Cornifrons ulceratalis (Lederer, 1858) in the north-western Mediterranean in October 2006. Ex. $=$ number of individuals sampled ( $>1$, several but number unspecified).

\begin{tabular}{|c|c|c|c|c|}
\hline Date & Ex. & Locality (Country) & Position & Reference \\
\hline $24-28$ Oct 2006 & $>1$ & Alaior, Menorca Island (Spain) & $39^{\circ} 55^{\prime} 50.30^{\prime \prime} \mathrm{N}, 4^{\circ} 08^{\prime} 23.95^{\prime \prime} \mathrm{E}$ & Honey et al. (2007) \\
\hline $25-28$ Oct 2006 & 7 & S'Albufera, Mallorca Island (Spain) & $39^{\circ} 47^{\prime} 18.02^{\prime \prime} \mathrm{N}, 3^{\circ} 06^{\prime} 19.85^{\prime \prime} \mathrm{E}$ & Honey et al. (2007) \\
\hline 25 Oct 2006 & 1 & Platja de Viladecans, Barcelona (Spain) & $41^{\circ} 16^{\prime} 32.10^{\prime \prime} \mathrm{N}, 2^{\circ} 03^{\prime} 59.41^{\prime \prime} \mathrm{E}$ & A. Cervelló, per. obs. \\
\hline 27 Oct 2006 & 2 & Esterri d’Àneu, Lleida (Spain) & $42^{\circ} 38^{\prime} 21.76^{\prime \prime} \mathrm{N}, 1^{\circ} 05^{\prime} 21.03^{\prime \prime} \mathrm{E}$ & J. Dantart, per. obs. \\
\hline 27 Oct 2006 & 1 & Graddé, Tarn (France) & $44^{\circ} 01^{\prime} 44.06^{\prime \prime} \mathrm{N}, 1^{\circ} 50^{\prime} 05.36^{\prime \prime} \mathrm{E}$ & Marney \& Marney (2007) \\
\hline $27-28$ Oct 2006 & 2 & Vendargues, Hérault (France) & $43^{\circ} 39^{\prime} 24.66^{\prime \prime} \mathrm{N}, 3^{\circ} 58^{\prime} 11.56^{\prime \prime} \mathrm{E}$ & Geniez et al. (2007) \\
\hline 27 Oct 2006 & $>1$ & Banyuls-sur-Mer, Pyrénées Orientales (France) & $42^{\circ} 29^{\prime} 00.08^{\prime \prime} \mathrm{N}, 3^{\circ} 07^{\prime} 29.51^{\prime \prime} \mathrm{E}$ & Geniez et al. (2007) \\
\hline 27 Oct 2006 & 1 & Fitou, Aude (France) & $42^{\circ} 53^{\prime} 32.93^{\prime \prime} \mathrm{N}, 2^{\circ} 58^{\prime} 27.09^{\prime \prime} \mathrm{E}$ & Geniez et al. (2007) \\
\hline 28 Oct 2006 & 7 & Esterri d’Àneu, Lleida (Spain) & $42^{\circ} 37^{\prime} 00.87^{\prime \prime} \mathrm{N}, 1^{\circ} 06^{\prime} 24.17^{\prime \prime} \mathrm{E}$ & J. Dantart, per. obs. \\
\hline 28 Oct 2006 & $>1$ & Cournonterral, Hérault (France) & $43^{\circ} 33^{\prime} 32.55^{\prime \prime} \mathrm{N}, 3^{\circ} 43^{\prime} 09.58^{\prime \prime} \mathrm{E}$ & Geniez et al. (2007) \\
\hline 29 Oct 2006 & $>1$ & Nissan-lez-Ensérune, Hérault (France) & $43^{\circ} 17^{\prime} 20.83^{\prime \prime} \mathrm{N}, 3^{\circ} 07^{\prime} 41.89^{\prime \prime} \mathrm{E}$ & Geniez et al. (2007) \\
\hline 31 Oct 2006 & 1 & Vic-la-Gardiole, Hérault (France) & $43^{\circ} 29^{\prime} 25.94^{\prime \prime} \mathrm{N}, 3^{\circ} 47^{\prime} 47.61^{\prime \prime} \mathrm{E}$ & Geniez et al. (2007) \\
\hline
\end{tabular}

a.m. (local time). The trap was left in open elevated areas overlooking the surrounding deciduous forests.

The possible origin of $C$. ulceratalis was investigated by means of backward-in-time air-mass trajectories. A 96-h back trajectory reaching Catalonia and the Balearic Islands at 12 UTC (Coordinated Universal Time) was calculated for each day between 22 October and 30 October 2006. Trajectories were run at 500 and $1,500 \mathrm{~m}$ a.s.l. using the Hybrid Single-Particle Lagrangian Integrated Trajectory (HYSPLIT-4) model of the National Oceanic and Atmospheric Administration (NOAA) (available at http://www.arl.noaa.gov/ready/hysplit4.html; Draxler \& Rolph, 2003). A height of $500 \mathrm{~m}$, corresponding to 1,000 $\mathrm{hPa}$ standard pressure level, was selected because previous data from vertical-looking radars indicate that the maximum transport of migrant insects over Europe occurs approximately at this level (Chapman et al., 2003). A height of 1,500 m a.s.1., roughly corresponding to the $850 \mathrm{hPa}$ standard pressure level, was also selected as being representative for transport in the lower troposphere since a relationship between the $850 \mathrm{hPa}$ wind direction and the prevailing weather patterns associated with the passage of cyclonic waves is well established (Dayan \& Lamb, 2003).

We also present here the meteorological scenarios responsible for the synoptic-scale wind system associated with the arrival of the moths. Weather charts from the NOAA showing mean pressure at sea-level and the geopotential height at $850 \mathrm{hPa}$ and 700 hPa were used.

\section{RESULTS AND DISCUSSION}

The most remarkable captures made during the two nights of moth-trapping were two (27 October) and seven
(28 October) specimens of C. ulceratalis, the first records of the species from Catalonia. Although this moth is listed by Agenjo (1966) in his catalogue of Spanish Lepidoptera (but not accompanied by precise data), we have been unable to find any further report of its presence in Spain (A. Vives-Moreno, pers. com.). There are, however, two recent records by Corley et al. (2000) from south Portugal (Algarve region). Likewise, $C$. ulceratalis has only been recorded sporadically from other countries along the northern shores of the Mediterranean Basin and on some Mediterranean islands (cf. Karsholt \& Razowski, 1996; Goater, 2005).

Other subtropical migrant species of probable African origin such as Spodoptera exigua (Hb.), Methorasa latreillei (Dup.), Heliothis peltigera (D. \& S.), Helicoverpa armigera (Hb.), Mythimna loreyi (Dup.), Agrotis ipsilon (Hfn.) and Agrotis segetum (D.\& S.) accompanied the captures of $C$. ulceratalis. This rather atypical composition of a moth community during an autumn sample in the Pyrenees coincided with a period of exceptionally warm weather. The highest daily minimum temperature recorded in October 2006 at the nearby meteorological station of Espot was $14.9^{\circ} \mathrm{C}$ on 30 October, while the average of the daily minima for the whole October was $8.7^{\circ} \mathrm{C}$ (www.meteocat.com). These abnormally high temperatures were the consequence of the presence of a depression over the Atlantic, which persisted up to 29
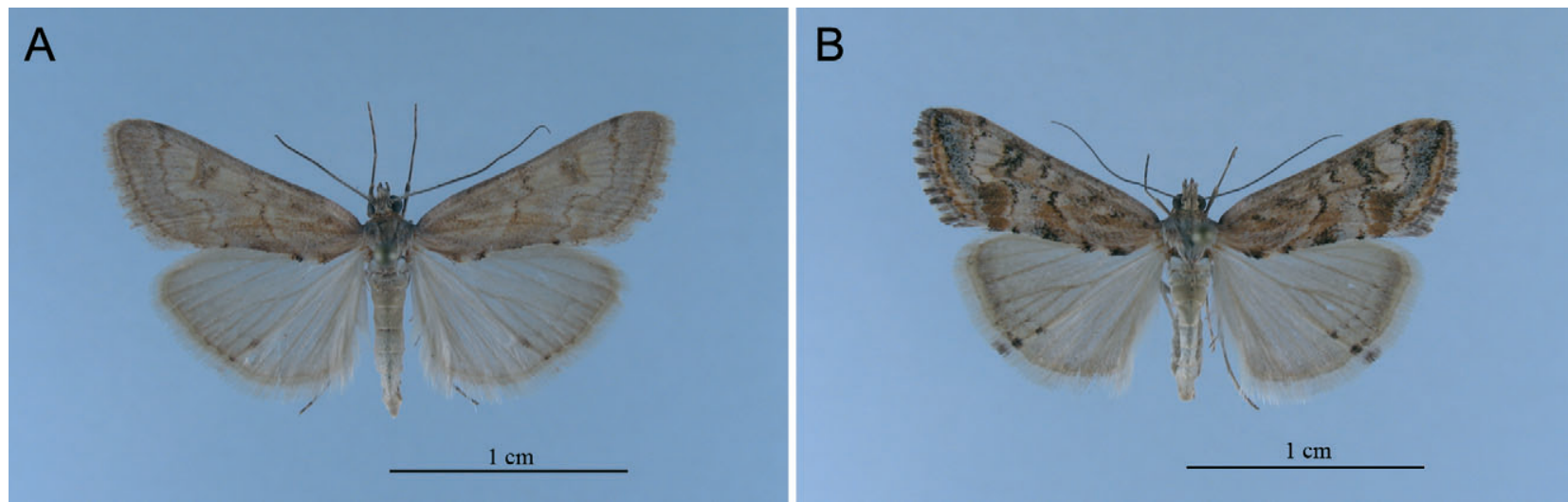

Fig. 1. Cornifrons ulceratalis (Lederer, 1858), male (A) and female (B) from Esterri d'Àneu, 27-28 Oct. 2006. 


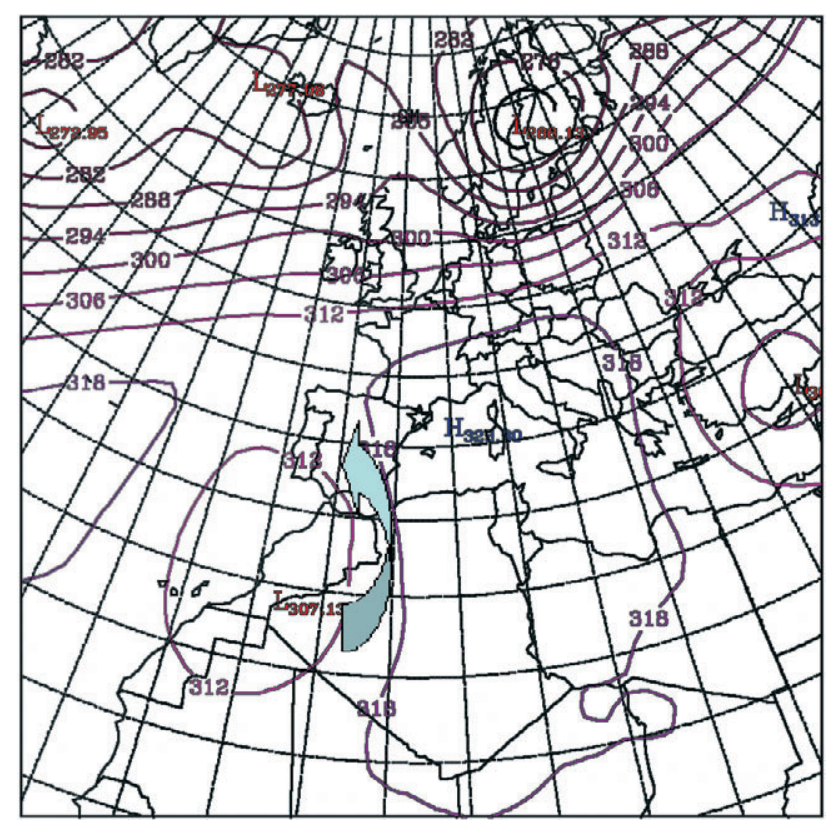

Fig. 2. Synoptic weather map showing mean pressure at the geopotential height at $850 \mathrm{hPa}$ on 27 October 2006. The arrow illustrates the movement of the south-westerly air mass.

October and sent a flux of south-westerly winds towards the western Mediterranean (Fig. 2). As a result of this meteorological situation, on the afternoon of 24 October and on subsequent days, the eastern Iberian coast, the south of France and the Balearic Islands were affected by the invasion of warm air accompanied by suspended dust originating in north Africa [Fig. 3; for more details see also the data provided by the Dust Regional Atmospheric Model - DREAM - (http://www.bsc.es/projects/ earthscience/DREAM)]. In fact, episodes of African

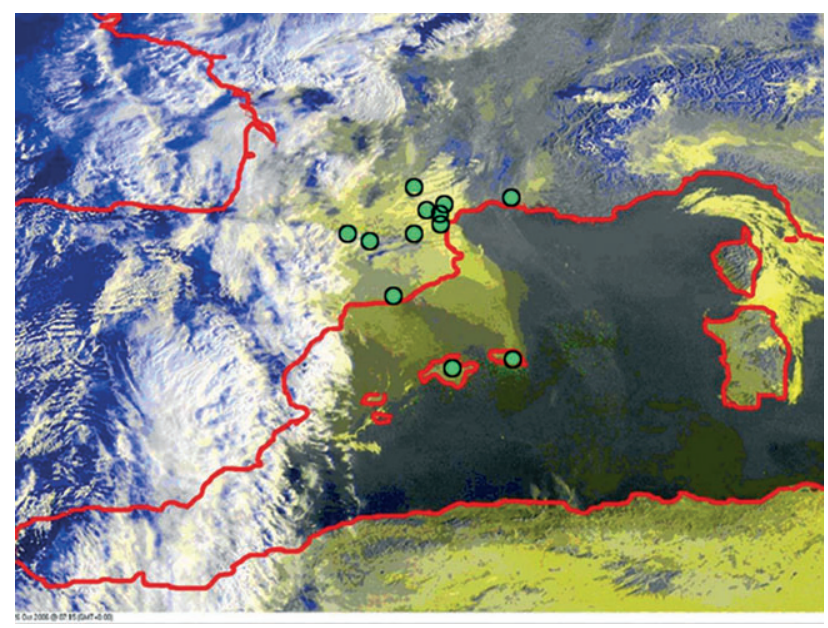

Fig. 3. Meteosat image from the visible band taken on 26 October 2006 at 06UTC. A cloud of Saharan dust (in yellow) moving from the African coast in Algeria towards the Mediterranean Sea has just passed over the Balearic Islands and is penetrating into Europe through Catalonia (north-eastern Spain) and southern France. Normal clouds are shown in white. Green circles correspond to sites where Cornifrons ulceratalis was recorded (see details in Table 1).

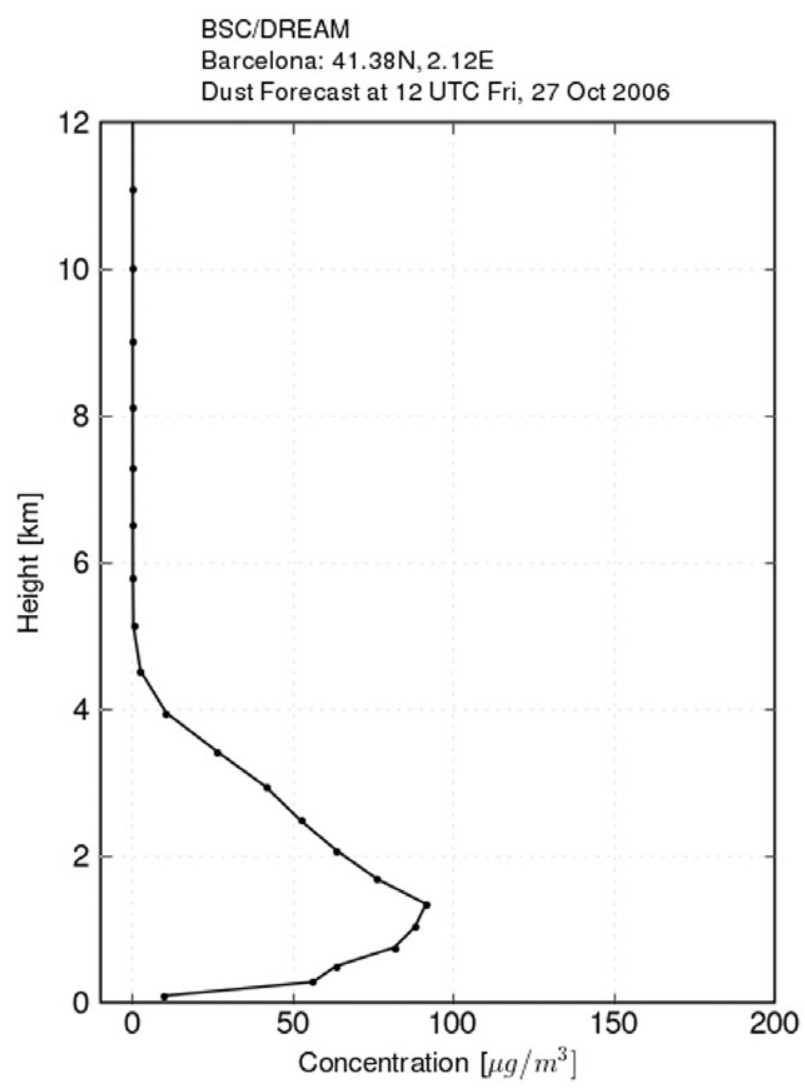

Fig. 4. Vertical profile of the dust concentration $\left(\mathrm{mg} / \mathrm{m}^{3}\right)$ over Barcelona on 27 October 2006, from the Dust Regional Atmospheric Model (DREAM)

winds in the north-western Mediterranean basin have been found to occur rather frequently, at a rate of 13 episodes per year (Escudero et al., 2005). Studies based on the chemical composition of African dust have identified the regions of the western Sahara and Tunisia as the main source areas for the dust deposited in north-eastern Spain (Àvila et al., 2007).

The spell of warm weather on October 2006 coincided with the first records of $C$. ulceratalis in several western Mediterranean areas (Table 1). Interestingly, high numbers of other African moths [e.g. Spodoptera cilium (Gn.), Earias insulana (Bdv.), Utethesia pulchella (L.), Spoladea recurvalis (Fabr.) and Nomophila noctuella (L.)] were also trapped by Honey et al. (2007) on the nights of 24-28 October.

All these facts strongly suggest that $C$. ulceratalis and other subtropical moths were blown by winds originating in Africa into the northern Mediterranean during this meteorological episode. Although no precise information on the flying heights of moths is currently available, an indirect estimation comes from data provided by DREAM, which indicates that the maximum levels of dust concentration were attained at 1,000-2,000 $\mathrm{m}$ (Fig. 4). Such an altitudinal range is perfectly plausible in light of the aerial collections that have confirmed moth migration occurring at elevations of up to 2,350 m (Westbrook, 2008). 
NOAA HYSPLIT MODEL

Backward trajectories ending at 1200 UTC 26 Oct 06 GDAS Meteorological Data

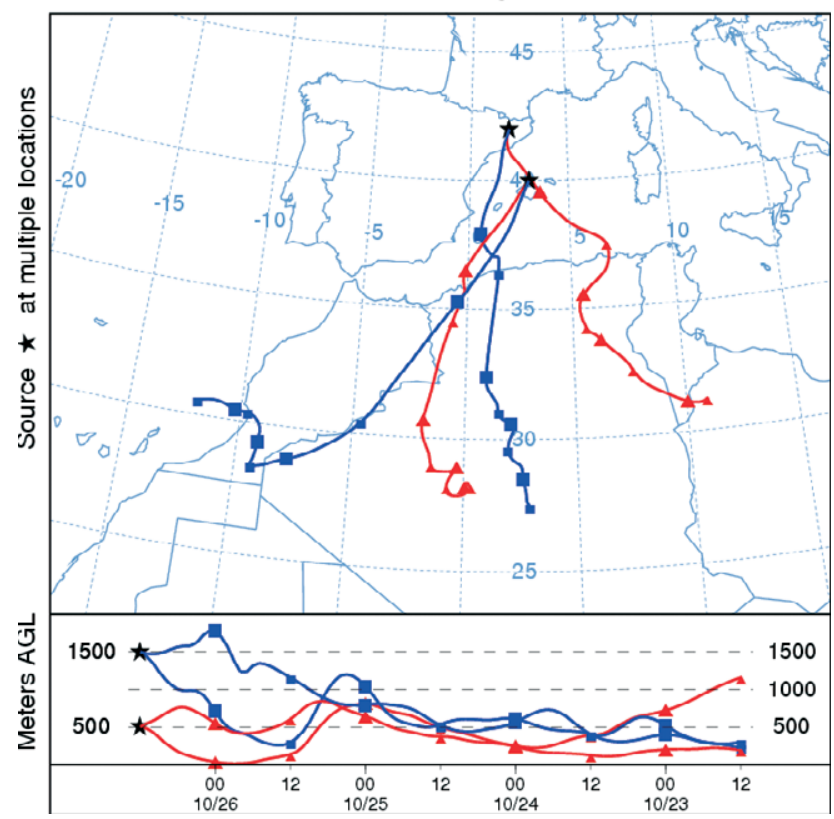

NOAA HYSPLIT MODEL

Backward trajectories ending at 1200 UTC 27 Oct 06 GDAS Meteorological Data

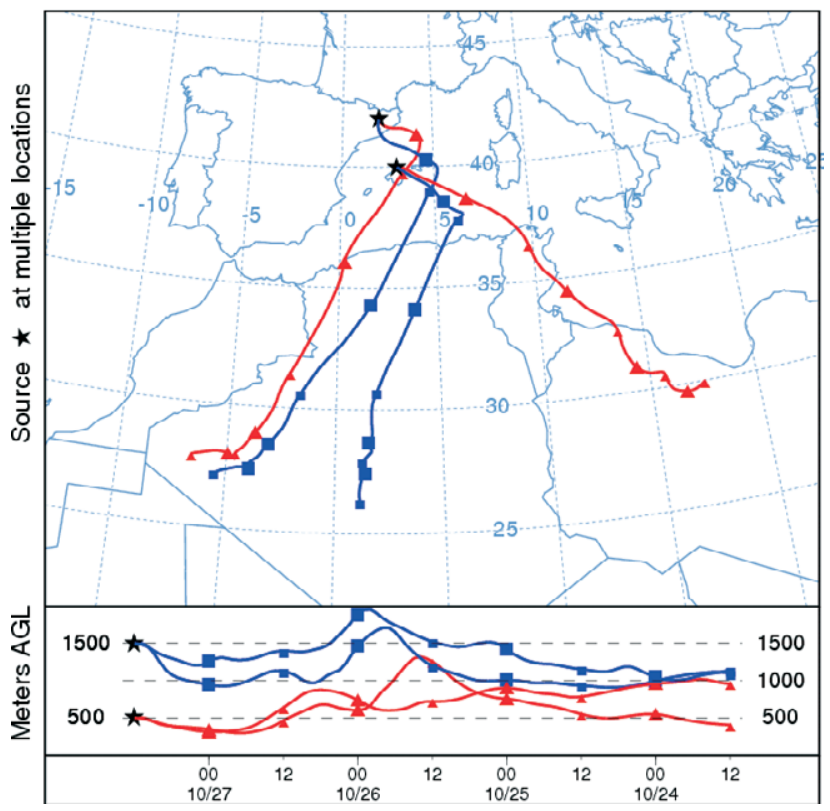

Fig. 5. 96-h back-trajectories at $500 \mathrm{~m}$ and 1,500 $\mathrm{m}$ a.s.l. arriving in Catalonia and the Balearic Islands at 12 UTC (Coordinated Universal Time) on the days 26 and 27 October 2006.

Back trajectories indicate that the moths most probably originated from an area located in Morocco and northern Algeria (Fig. 5). C. ulceratalis can be extremely abundant in this area, and Dumont (1929) described how the sheer size of the swarms attracted to lights made the air difficult to breathe. Although $C$. ulceratalis is considered as a non-migratory species, the large numbers that reached the western Mediterranean in October 2006 indicate that, under some conditions (e.g. when large densities are attained or when the weather is unusually warm), part of the population may behave in a migratory way and engage in ascending flights (e.g. Chapman et al., 2008; Westbrook, 2008) before getting caught up in highaltitude airstreams. In any case, we consider that this invasion provides a clear example of the so-called "pied piper" phenomenon.

There are at least two reasons to believe why the chances that these moths arriving in the western Mediterranean would establish a population were negligible. Firstly, this desert species would be unable to survive the extremely cold winter temperatures; and secondly, the host plants commonly used in Africa [e.g. the crucifer Henophyton deserti and the Pedaliaceae Sesamum indicum (sesame); Dumont, 1929] are not present in this area. However, the sporadic appearances of genuine African species in Europe and, especially, in the northern Mediterranean Basin, are expected to become more common in the future in the context of warming climate (e.g. Sparks et al., 2007). Not only will insect wind-borne transport be facilitated under future climate change scenarios, but associated temperature increases will make it more likely that populations of such species will eventually establish themselves by adapting to local hosts and potentially reaching pest levels in new areas (Cannon, 1998). Therefore, the monitoring of this process will become an essential issue over the coming years.

ACKNOWLEDGEMENTS. A. Vives-Moreno provided data on the distribution of Cornifrons ulceratalis, while A. Cervello kindly provided information about its capture. J. Chapman, K. Mikkola, D.R. Reynolds and two anonymous referees made helpful comments on the MS.

\section{REFERENCES}

Agenjo R. 1966: Catálogo ordenador de los lepidópteros de España. Quadragésimo tercera familia: Pyraustidae. Graellsia 22 (supplement without page numbers).

Àvila A., Alarcón M., Castillo S., Escudero M., García Orellana J., Masqué P. \& Querol X. 2007: Variation of soluble and insoluble calcium in red rains related to dust sources and transport patterns from North Africa to northeastern Spain. J. Geophys. Res. 112, D05210, doi:10.1029/2006JD007153.

BRETHERTON R.F. 1983: The incidence of migrant Lepidoptera in the British Isles. In Heath J. \& Emmet A.M. (eds): The Moths and Butterflies of Great Britain and Ireland. Vol. 10. Noctuidae (Part II) and Agaristidae. Harley Books, Colchester, pp. 9-34.

Brown D.C.G. 1996: Rare migrants during October 1995. Entomologist's Rec. J. Var. 108: 74-76.

CANNON R.J.C. 1998: The implications of predicted climate change for insect pests in the UK, with emphasis of non indigenous species. Global Change Biol. 4: 785-796.

Chapman J.W., Reynolds D.R., Smith A.D., Riley J.R., Pedgley D.E. \& WoIwoD I.P. 2002: High-altitude migration of the diamondback moth Plutella xylostella to the U.K.: a study using radar, aerial netting, and ground trapping. Ecol. Entomol. 27: 641-650. 
Chapman J.W., Reynolds D.R. \& Smith A.D. 2003: Verticallooking radar: a new tool for monitoring high-altitude insect migration. Bioscience 53: 503-511.

Chapman J.W., Reynolds D.R., Mouritsen H., Hill J.K., Riley J.R., Sivell D., Smith A.D. \& Woiwod I.P. 2008: Wind selection and drift compensation optimize migratory pathways in a high-flying moth. Curr. Biol. 18: 514-518.

Corley M.F.V., Gardiner A.J., Cleere N. \& Wallis P.D. 2000: Further additions to the Lepidoptera of Algarve, Portugal (Insecta: Lepidoptera). SHILAP Revta Lepid. 28: 245-319.

DAYAN U. \& LAMB D. 2003: Meteorological indicators of summer precipitation chemistry in central Pennsylvania. Atmosph. Envir. 37: 1045-1055.

DRAKE V.A. \& FARROW R.A. 1988: The influence of atmospheric structure and motions on insect migration. Annu. Rev. Entomol. 33: 183-210.

DraXler R.R. \& RolPh G.D. 2003: HYSPLIT (HYbrid SingleParticle Lagrangian Integrated Trajectory) Model access via NOAA ARL READY website (http://www.arl.noaa.gov/ ready/hysplit4.html), NOAA Air Resources Laboratory, Silver Spring, MD, USA.

Dumont C. 1929 : Note biologique sur les premiers états de Cornifrons ulceratalis Ld. (Lep. Pyralidae) et diagnose d'une forme nouvelle. Bull. Soc. Entomol. Fr. 1929: 301-306.

Escudero M., Castillo S., Querol X., Àvila A., Alarcón M., Viana M.M., Alastuey A., Cuevas E. \& Rodríguez S. 2005: Wet and dry African dust episodes over eastern Spain. J. Geophys. Res. 110, D18S08 doi:10.1029/2004JD004731.

French R.A. 1969: Migration of Laphygma exigua Hübner (Lepidoptera: Noctuidae) to the Bristish Isles in relation to large-scale weather systems. J. Anim. Ecol. 38: 199-210.

Gatehouse A.G. 1997: Behavior and ecological genetics of wind-borne migration by insects. Annu. Rev. Entomol. 42: 475-502.

Geniez P., Hollingworth T. \& Varenne T. 2007: Observations de trois espèces de lépidoptères nouvelles ou rarement signalées de France continentale (Lepidoptera, Pyralidae \& Gelechiidae). Rev. Ass. Roussillonn. Entomol. 16: 73-75.

Goater B. 2005: Evergestinae. In Huemer P. \& Karsholt O. (eds): Microlepidoptera of Europe. Pyraloidea I (Crambidae: Acentropinae, Evergestinae, Heliothelinae, Schoenobiinae, Scopariinae). Part 4. Apollo Books, Stenstrup, pp. 69-107, 208-223, 244-256, pls 2-3.

Honey M.R., Férriz I. \& RidDIford N.J. 2007: Additional evidence supporting the migration of Cornifrons ulceratalis Lederer (Lep.: Crambidae, Evergestinae) in the Mediterra- nean region in October 2006. Entomologist's Rec. J. Var. 119: $237-238$.

Johnson C.G. 1969: Migration and Dispersal of Insects by Flight. Methuen, London, 763 pp.

JoHNSON S.J. 1995: Insect migration in North America: synopticscale transport in a highly seasonal environment. In Drake V.A. \& Gatehouse A.G. (eds): Insect Migration: Tracking Resources Through Space and Time. Cambridge University Press, Cambridge. pp. 31-66.

Karsholt O. \& RazowsKi J. (eds) 1996: The Lepidoptera of Europe. A Distributional Checklist. Apollo Books, Stenstrup, $380 \mathrm{pp}$.

Kettlewell H.B.D. \& Heard M.J. 1961: Accidental radioactive labelling of a migratory moth. Nature 189: 676-677.

Marney M. \& MARnEY B. 2007: Cornifrons ulceratalis (Lederer, 1858) (Lep.: Crambidae) new to France and Syncopacma albifrontella (Heinemann, 1870) (Lep.: Gelechiidae): first published French record. Entomologist's Rec. J. Var. 119: 56-58.

McNeIL J.N. 1987: The true armyworm, Pseudoletia unipuncta: a victim of the pied piper or a seasonal migrant? Insect Sci. Appl. 8: 591-597.

MiKKOLA K. 1967: Immigrations of Lepidoptera, recorded in Finland in the years 1946-1966 in relation to air currents. Ann. Entomol. Fenn. 33: 65-99.

MiкKola K. 1986: Direction of insect migrations in relation to the wind. In Danthanarayana W. (ed.): Insect Flight: Dispersal and Migration. Springer, Berlin, pp. 152-171.

Pedgley D.E., Reynolds D.R. \& Tatchell G.M. 1995: Longrange insect migration in relation to climate and weather: Africa and Europe. In Drake V.A. \& Gatehouse A.G. (eds): Insect Migration: Tracking Resources through Space and Time. Cambridge University Press, Cambridge, pp. 3-29.

Reynolds D.R. \& Riley J.R. 1997: Flight Behaviour and Migration of Insect Pests: Radar Studies in Developing Countries. NRI Bulletin 71, Natural Resources Institute, Chatham, 114 pp.

Sparks T.H., Dennis R.L.H., Croxton P.J. \& CAde M. 2007: Increased migration of Lepidoptera linked to climate change. Eur. J. Entomol. 104: 139-143.

WALKER T.J. 1980: Migrating Lepidoptera: are butterflies better than moths? Fla Entomol. 63: 79-98.

WestвRooK J.K. 2008: Noctuid migration in Texas within the nocturnal aeroecological boundary layer. Integrative Comp. Biol: : doi: 10.1093/icb/icn040.

Received July 16, 2008; revised and accepted September 26, 2008 
